\title{
Company legitimacy and Sustainable Operations: The Case of Apparel Manufacturers of Sri Lanka
}

\author{
S. Sapukotanage ${ }^{1}$, B. N. F. Warnakulasuriya ${ }^{2}$, \& S. T. W. S. Yapa ${ }^{2}$ \\ ${ }^{1}$ The Open University of Sri Lanka, Sri Lanka \\ ${ }^{2}$ University of Sri Jayawardenapura, Sri Lanka \\ Correspondence: S. Sapukotanage, The Open University of Sri Lanka, Sri Lanka.
}

Received: October 23, 2020

doi:10.5539/ibr.v13n12p42

\begin{abstract}
In the highly sustainability conscious business environment, organizations face the pressure of their stakeholders to carryout sustainable operations. In this context organizations take many sustainability measures to make themselves socially responsible. Literature suggests that the power of the stakeholder determines the extent to which an organization adheres to stakeholder requirements due to their dependence on such stakeholders. Therefore whether the behaviours of organizations towards sustainability could be treated as 'socially responsible' and whether they really fulfill the social contract they have entered into, become questionable. A qualitative study was carried out based on in depth interviews with senior managers of four apparel manufacturing and exporting firms of Sri Lanka to investigate how organizations in a developing country fulfill their social contract towards sustainability in international operations since these firms operate with powerful international customers. The thematic analysis conducted based on the interview data of the apparel manufacturers of Sri Lanka reveal a similarity in the results to what has been identified in literature in relation to the manner manufacturers respond to stakeholder requirements. The extent to which they meet the requirements of their stakeholders has been confined to just a legal requirement to satisfy the powerful customers. Although there was legitimacy in their behavior it raised doubts for the researcher about the fulfillment of the social contract through this behavior since these manufacturers were not concerned about certain aspects of sustainability which the customers were not interested in. One such main factor was the sustainability of their suppliers. These findings inform policymakers the need to educate the apparel exporters of their responsibility towards sustainability because the social acceptability that comes with legitimacy may be more important than economic viability. The contribution of this study to knowledge is in terms of how the dependence of manufacturers in developing countries, influence their adherence to stakeholder requirements.
\end{abstract}

Keywords: company legitimacy, social contract, sustainable operations

\section{Introduction}

The Stakeholder Theory states that organizations should be managed in the interest of all their constituents, not only in the interest of shareholders (Laplume et al., 2008). It implies that the organization has to look after the interests of all parties who affect its operations as well as those who are affected by its operations (Freeman, 1994). Foley (1995) defines stakeholders as those parties which a business identifies as those who are interested in and/or affected by the activities or existence of that business and are capable of causing the enterprise to fail or could cause unacceptable levels of damage, if their needs are not met. With the importance assigned to all stakeholder groups of an organization, the primary relationship between business and society which continued to be an economic one has changed to be one with rising public concern about the social and environmental impacts of economic growth. The principle of legitimacy focuses on obligations and sanctions that determine the boundaries of business- society relationships. Then the role of organization becomes one that of maintaining a policy consistent to both external and internal interests (Banerjee, 2008). This notion is further established by Warren (1998) when he explains that company legitimacy is about corporate governance and accountability and how this is related to shareholders and stakeholders.

Increased legislation in areas of social welfare and environmental protection which came into practice as a result led many corporations to assess the social and environmental impacts of their business activity (Banerjee, 2008). Companies extended their focus beyond traditional economic objectives to a triple bottom line (TBL) approach 
that simultaneously accounted for economic, ecological and social performance (Hollos et al., 2012). This incorporated Elkington's (1998) definition of sustainable performance comprising of people, planet and profit. Meeting the social needs of stakeholders is human sustainability (Perrot, 2014) where the organization contributes to the personal wellbeing and development of the work force and to the wellbeing of the community and the society at large. Ecological sustainability is maintained by an organization through the minimization of the harmful effects of its operations to the natural environment. Economic sustainability is ensured when the financial concerns of the stakeholders are satisfied. The explanation of Schaltegger and Burritt (2014) highlights how the level of sustainable performance of a firm needs to be looked at from a Triple Bottom Line approach. Accordingly, the following items need to be identified in determining whether a firm is sustainable or not.

- Existing levels of negative social and environmental impacts and how they relate to economic performance

-Improvements (i.e reductions of negative social and environmental impacts) and what effect these activities have on economic performance

-The social, ecological and economic effects of actions taken targeting improvement.

Only if performance is measured along these lines can the stakeholder requirements be satisfied. As explained earlier when organizational performance is assessed against the expectations of a variety of stakeholder groups, more attention needs to be paid to the impact of organization's activities on the natural environment and the society while assessing their economic implications. Unless the environmental and social management are linked to the economic success an overall picture of sustainable performance of the firm cannot be obtained since environmental and social scarcities are only partially reflected in economic transactions. As a result, the economic contribution of environmental and social management will remain unclear. Therefore, unless a holistic figure is not calculated a clear picture of sustainable performance cannot be derived. The increasing importance of sustainable behavior in business even enhanced its impact on supply chain management. This indicates of an extension in the scope of supply chain management to emphasize the importance of the balanced use of natural, social and economic capital for the continued wellbeing of organizations through supply chain activities, with the interest of stakeholders moving towards sustainable operations.

Although there is agreement that sustainability is a holistic concept, the performance that has been identified as sustainable in literature was confined mainly to environmental performance in many empirical studies (Carter and Rogers, 2008; Seuring and Muller, 2008; Pullman and Dillard, 2010; Reuter et al., 2010; Sarkis et al., 2010). At the same time there are also organizations which have extended their sustainability efforts even to the supply chains of which they are members. Hollos et al. (2012) explain how firms increasingly respond to the need for sustainability in their upstream supply chain with an example. E.ON UK established a 'responsible procurement' policy which focuses on human rights, minimization of environmental impacts and maintenance of high standards of ethics and business integrity. In implementing the policy E.ON UK developed joint social and environmental standards with its suppliers. The importance given to sustainability in the fashion industry of Europe is clearly evident from another empirical example. In the fashion industry, disposable fashion under the fast fashion concept (Choi, 2013) has become a global trend which has its fundamental root in Europe. Under this trend, fashion supply chains must be highly responsive and able to produce products even in a very small quantity to satisfy the market needs. This was found to be environmentally unfriendly because the consumers will only use the fashion items for a short period and then replace them by new ones. However, from the supply chain side, the fast fashion concept helped to better match supply and demand and lowers inventory levels. Moreover, since many fast fashion companies (such as Zara) adopted a local sourcing approach and get supply from local manufacturers, the corresponding carbon footprint (Choi, 2013) was much reduced (and hence more environmental friendly) compared with the more traditional offshore sourcing. This example shows how keen are some organizations to maintain a balance between the three pillars of sustainability. So empirical evidence highlight the fact that there are organizations that both adopt sustainability measures as well as those which do not.

The above behavior of companies is identified by Regan (1998) in two different contexts in relation to role of a company in maintaining sustainability. The corporation can be inherently guided by self- interest or it may operate on the basis of civic virtue'. According to him the second notion refers to the legitimacy of a corporation and its role in society. While the legitimacy principle is explaining the importance of addressing the needs of the society and the accountability of organizations literature addresses instances where companies may consider more of satisfying their own needs than those of the society. Windsor (2001) argues that discourses related to the relationship between business and society are based on corporate interests, not social interests. Researchers in the strategic legitimacy tradition have highlighted the opportunistic nature of corporate social and environmental reporting which is used more as a legitimization device than as an accountability mechanism (Chelli et al., 2014). 
They have even stated that voluntary disclosure often involves disseminating misleading communications. Woodward et al. (1996) too explain how legitimacy could be manipulated. They say that unlike many other "resources", it is a "resource" that the organization is considered to be able to impact or manipulate through various disclosure-related strategies.

Regan (1998) refers to this as the self- interest assumption where corporations will not usually take the socially responsible course of action unless it meets their profitability criteria. This behavior of organizations could be due to their legitimacy being confined to one or few forms of legitimacy where legitimacy is regulative, normative and cognitive (Wei et al., 2017). The regulative dimension relates to the firm's conformity to laws and regulations. The normative dimension relates to the firm's moral values and ethical principles. The cognitive dimension relates to stakeholders' social cognitions as they relate to an industry's business practices. As Warren (1998) explains it is possible that the legitimacy of an organization is not regulative, normative and cognitive. For example, the moral character of a company is largely determined by the kind of authority its executive sustains and by how that authority is used inside and outside the company. An explanation by Islam and Deegan (2008) also establishes that social responsibility may not be always exercised at its best. The authors state that more critical the stakeholder's resources are to the continued viability and success of the organization, the greater the expectation that stakeholder demands will be addressed. They further explain that the processes an organization will adopt will be tied to efforts to survive in a profitable manner, rather than being driven by any underlying ethical or moral imperatives. Where particular stakeholders or societies are deemed to be important to an organization's survival, then an organization will make efforts to ensure that its activities and processes are consistent with their respective expectations. However, according to the Institutional theory, a firm gains legitimacy by confirming to the rules, norms, and social expectations of an institution within the assumption that the institution is well established and functional (Wei et al.,2017).

Then a question arises as to whether all organizations which exercise company legitimacy meet their social contract at the same level. Deegan (2002) explains that the extent to which a company meets its social contract may differ due to various reasons. Accordingly it may vary with how managers react to particular events in the specific national, historical and cultural context. Researcher identifies the dependence of manufacturing firms as one such context which determines how managers react to particular events (Huo et al., 2018). Buyer-supplier relationships are characterized by an asymmetric allocation of resources, which results in structural interdependence between the exchange parties. Because different firms own different resources and specialize in different activities, a firm needs to exchange with other firms to get the resources it needs. Meanwhile, firms facing great competition and uncertainty are motivated to build long-term, intimate relationships with their partners to secure their competitive advantage, which further strengthens inter-firm dependence. Therefore one party relies on the other in maintaining a relationship to achieve expected goals. When one party realizes its dependence on the other, it will take very careful actions to ensure every move fits the rule of reciprocity. In other words interactions between partners will be based on the expectation of giving and receiving relational benefits. With the growing power of giant retail groups, the retailer assumes the leadership role of the whole channel which has become an important topic in modern supply chain management (Agrawal and Smith, 2015).This amounts to the power of the buyer (customer) in the buyer-led fashion supply chain. Apparel industry of Sri Lanka is an industry to which sustainability principles are extremely relevant since their international buyers (customers) are sustainability conscious. There have been studies on the sustainability practices of these apparel manufacturing organizations. However those practices have not been looked at from a perspective where they have met the social contract through such practices. In a context where power of the stakeholder determines the extent to which an organization adheres to stakeholder requirements and apparel manufacturing organizations of Sri Lanka being dependent on the giant retailers it was timely to conduct a study on how firms in the apparel manufacturing industry of Sri Lanka maintain their social contract within their boundaries of legitimacy. Most studies to date have been conducted in the context of developed countries (Luken, 2006; Hussain et al., 2012) despite the obvious relevance to developing countries. These reasons provide adequate evidence for the need to address this empirical gap. Here, the information specific to Sri Lanka are considered from a developing country perspective.

The rest of the paper is structured as follows: It begins with a review of literature in relation to the sustainable operations of organizations from the perspective of legitimacy theory. Method of the study is explained next. Lastly this paper presents the results and discusses the main implications of the findings.

\section{Review of Literature}

\section{Sustainable Operations}

Environmental issues, such as climate change and greenhouse gas (GHG) emissions, and social concerns, such 
as the use of child labour have come into practice as a result of the operations of organizations. All organizations' individually and supply chain members are forced to carry out sustainable practices at both organizational and supply chain boundaries where they integrate a wider set of objectives than just reaching an acceptable level of economic performance. Further various environmental legislations as well as standards and reporting frameworks are indications of the need to balance the three dimensions of social, environmental and economic sustainability (Zhu and Sarkis, 2004; Wilding et al., 2012)

When an organization is a member of a supply chain the activities of other members of the chain too amounts to its sustainable operations. Sourcing of materials is an activity for which many organizations form relationships with other organizations. The parties with whom they build up the relationship are the 'suppliers'. These relationships with the supplier also matter to the manufacturer sustainability since the materials that the supplier provides are used in production. Krause and Ellram (1997) explain that a company is no more sustainable than the suppliers from which it sources, highlighting the importance of suppliers in ensuring sustainability along supply chains. Suppliers have been identified as one of the main sources of environmental and ethical risks for customer companies by Moretto et.al (2012) as well. Liker and Choi (2004) explain that businesses are increasingly relying on their suppliers to reduce costs, improve quality and develop new processes and products faster than their rivals' vendors can. As a result, in managing their sourcing relationships along the supply chain manufacturers (buyers) get involved in selecting, sourcing and developing suppliers (Cox,2004) to make sure that sustainability concerns are satisfied. Since both the supplier and the buyer are members of a single chain the performance of the entire chain is in the interest of both parties. It is accepted that in the event of an economic exchange both parties to an exchange can gain through collective operation (Granovetter, 1992).

\section{Company Legitimacy}

The concept of 'company legitimacy' is addressed in Legitimacy Theory. According to Islam and Deegan (2002) the understanding of this theory is that organizations attempt to ensure that they are perceived as operating within the bounds and norms of their respective societies. In other words, they attempt to ensure that their activities are perceived by outside parties as being "legitimate". Chelli et al (2014) further explain that it is in order to honour the social contract that organizations constantly strive to ensure that stakeholders view their activities as legitimate. Wei et al (2017) say that legitimacy refers to a generalized perception or assumption that the actions of an entity are desirable, proper or appropriate within some socially constructed system of norms, values, beliefs and definitions. Though the bounds and norms in conducting these activities need not be considered to be fixed. They change over time, thereby requiring organizations to be responsive to the ethical (or moral) environment in which they operate (Islam and Deegan, 2008).

Legitimacy is identified as vital to a firm's survival because it ensures a continuous inflow of external resources and support from various stakeholders. Referring to Lindblom (1994), Islam and Deegan (2008) identify what organizations are supposed to do in order to reach legitimacy which she identifies as a status. She identifies the process that leads to an organization being judged legitimate, as legitimation. Accordingly when a disparity, actual or potential, exists between the two value systems what the organization values and what is valued by the society, there is a threat to the entity's legitimacy. It is something that is conferred upon the organization by society, and it is something that is desired or sought by the organization. Researchers have observed that organizations attempt to signal legitimacy mainly through their activities related to Corporate Social Responsibility.

\section{Social Contract}

The concept of social contract is referred to the extent to which the organization has met the responsibilities imposed upon it. It implies that an organization is legitimate whilst ensuring that it is society at large, not the organization which determines the rules of accountability (Gray et al., 1998). While social contracts are not legally binding and only refer to the common understanding, they on the one hand outline what rights and obligations exist and on the other hand give protection against illegitimate action (Wallenburg and Schäffler, 2014).

\section{Method}

This study adopted a qualitative approach since most of the evidence related to Environmental Corporate Social Responsibility has been taken from qualitative or case studies (Wei et al.,2017). The unit of analysis was the organization. Organizations were selected from the apparel manufacturing and exporting industry. There were number of reasons for selecting this industry. Most importantly the apparel manufacturing and exporting industry of Sri Lanka provides an opportunity to consider how the social contract in relation to sustainable operations is maintained. It is an industry stakeholder pressures influence the sustainable operations. A second reason for 
selection was related to the scope of the study. Researcher was interested in recognizing company legitimacy at the level of ensuring the sustainability of their own suppliers. Apparel manufacturing industry is one in which the relationships with supplier organizations is clearly evident. Four in depth interviews ranging from 1-2 hours were conducted with senior managers of four leading apparel manufacturing and exporting organizations in Sri Lanka. Purposive sampling was adopted to select the respondents. Two of the companies were large while the other two were medium sized when the number of employees was concerned. The respondents served those organizations in the managerial capacity with more than 05 years of experience. Researcher found the knowledge and the experience of the respondents sufficient enough to provide information about the sustainable operations of their organizations. The list of open ended questions the researcher carried with her served the purposes of an interview guide. Through these questions the researcher attempted to understand the perceptions of the manufacturers about the sustainable practices. It was not the sole concern. Beyond that the main objective of the researcher was to identify the extent to which social contract is maintained by their sustainable operations. So the researcher examined whether the sustainability conscious manufacturers go to the extent of ensuring the sustainability of their suppliers since all that constitutes the social contract they enter into.

The interviews were audio recorded with the permission of the interviewees. They were transcribed and data analysis of the transcripts was carried out according to the six step approach of thematic analysis suggested by Braun and Clarke (2006). Three themes were identified after a rigorous process of coding Table 1 provides a summary of the coding process.

Table 1. Summary of the Coding Process

\begin{tabular}{ll}
\hline CODES & THEMES \\
Apparel exporters' coalition & Adherence to Sustainability measures \\
Legal compliance & \\
Environmental protection & \\
Social compliance & \\
CSR activities & Supplier power \\
Powerful & \\
Forcing & \\
International suppliers & \\
Insignificant buyer & \\
Chemical content & \\
Worried customers & \\
Right things & \\
Important Customers & \\
\hline
\end{tabular}

\section{Results}

The results presented in this section are the outcomes of the interviews with the managers. They are in relation to their responses to the open ended questions presented to them during the interview.

\section{Perceptions on sustainable practices}

The managers were asked whether they take any measures to make their organizations sustainable. Two of the respondents were aware of the word 'sustainable' while the researcher had to explain its meaning to the other two respondents. After a further explanation by the researcher the two managers who were not familiar with the term sustainability inquired whether it is related to compliance. Detailed questioning on what they implied by compliance revealed that it is sustainability that they refer to as compliance. All four managers were in agreement about their perceptions with regard to the exercise of sustainable operations. Following are some of the statements selected from the interviews providing evidence that they were engaged in environmental as well as social practices.

Our customers are also emphasizing on sustainability with overall interest, social or environment. We are 
working with them to develop the communities they source from.

On a monthly basis we monitor water levels, energy levels against the standards set by Board Of Investment (BOI).

We take factory based measures to address social concerns.

We have CSR projects helping schools and hospitals.

There is a programme called 'Human go Beyond' where we give training facilities to our workers other than the job related training.

In the conversations researcher found that they were more conscious about the cost of such activities since price competition was their priority.

Perceptions on sustainable practices of the suppliers

They specifically stated their views on the sustainable operations of the suppliers in the following manner:

Some large suppliers in India have a tangible say in their work. But China is not bothered about sustainability.

Environment sustainability is more with customers rather than with suppliers.

Perceptions on governing sustainable practices of the suppliers

The next question posed to them by the researcher was about their role in the sustainability efforts of suppliers. Their response was unanimous about the inability to influence suppliers since they are larger than the manufacturers. They identified three categories of suppliers; the largest international suppliers of fabric, the second largest local knitted fabric and thread suppliers and the third largest local suppliers of packing materials. What the managers said was that they are only a small percentage among the buyers of international fabric suppliers. So it is hard to influence them. But the local suppliers could be influenced. A few statements to highlight the majority view are:

We wanted to work with suppliers to make them more sustainable. But specifically you should understand that the suppliers of raw materials are larger than our manufacturers in the apparel industry. For them we are just $10 \%$. Because of that we are unable to influence them that much. If we have a $30 \%, 40 \%$ then we can. That is what is happening to us. We are focusing on 2,3 customers.

But for the local companies Sri Lankan companies are more important. We can ask them to adhere to our requirements and if they don't, we move to some other supplier.

Then the researcher questioned whether the manufacturing organization could admit that they are offering sustainable products when the suppliers from whom they source the raw materials to produce those goods are not sustainable. Their response was strange. They said that they mainly source from suppliers suggested by the customers and therefore customers will look into the sustainability of those suppliers. Some of their views were:

For that global apparel community has come up with a SAC sustainable apparel coalition

There is an evaluation HIGG Index .They focus on the whole supply chain. All high end retailers are registered. Suppliers are also registered

When we are looking for a supplier we do not see. But our customers see

So we mostly deal with our customers and their requirements and if it is possible for us

And the manufacturers were confident that their customers could be convinced of their sustainability at the existing level of supplier performance. They explain;

For our customer Sri Lanka is a keen area from where they can get responsibly produced goods. In the global apparel industry we are a socially responsible country for exports in the global context.

The social aspect in Sri Lanka is high. So our customers are more confident than with others.

Sri Lanka is considered a socially responsible nation.

JAAF made a big contribution to develop that mindset.

Then the researcher asked whether isn't it important for them to work closely with suppliers on sustainability measures than with customers. The respondents questioned what is the incentive for them to do that. Their views are represented by the following statements.

If a supplier is giving a price reasonable, having the best quality and the best delivery we don't want to 
worry about the areas related to the environment aspect

In that context we think of some of the areas related to the environment aspect

Specifically chemical compliance

Chemical content mostly matter at the stage of fabric manufacturing with regard to dying etc.

There is an initiative called the ZDHC Zero Discharge of Hazardous Chemicals

2,3 years back this was introduced by Green Peace where the Dirty Laundry and Dirty Laundry 2 addressed that most of the high end customers are not doing what they say.

Customers wanted their suppliers to make sure that they do the right thing.

They cannot contain the chemicals the customers have identified in the Restricted Chemicals List (RSL) in the final garment.

If they are contained in the garment there will be negative consequences for the health and if they are washed away then the fauna in their countries will be affected.

So further they have emphasized on the Material Responsible List (MRL)

Finally the researcher asked for the views of the respondents about the impact of making their suppliers sustainable, on their competitive advantage. They admitted that it will be an added advantage. While admitting that they say that without themselves being not sustainable how can they influence others.

It is an added point

By 2020 we are planning to have an index to evaluate the content in each garment and its impact on the environment.

But the thing is if you want to reduce. We can't directly do. But the brands can.

If we have not done the best until such time we are confident that we are working within the environment we cannot go and say who are working very much on that.

\section{Analysis and Discussion}

According to the codes identified by the researcher within the transcribed interviews three themes were identified. They were: 'Adherence to Sustainability measures', 'Supplier power' and 'Customer imposed Sustainability measures'.

In summarizing the perceptions along those three themes the researcher could realize that the power of the customer has played a significant role in sustainable acts of apparel manufacturing organizations of Sri Lanka. The sustainability initiatives were mainly carried out to satisfy the requirements of the customers. They were not concerned about the sustainable measures if the customers did not expected them to do so.

The perceptions of the respondents showed that the manufacturers do not find them responsible for the actions of the suppliers because the customers who buy the final product do not question about the sustainability of suppliers. When the customer is concerned about the chemical content of the fabric produced by the supplier only, they will be concerned over the chemical content of the fabric. But still they were not worried whether the fabric was produced using child labour or not. This finding is consistent with the Stakeholder Theory which says that the extent of meeting the stakeholder requirements will depend on the power of the stakeholder. Though the social contract that emanates from social responsibility keep them bound to look into every aspect of sustainability. As stated in paragraphs above the researcher is of the view that this behavior of the manufacturers can be attributed to their dependence on the strong retailers who are their buyers. On one hand adherence to sustainable practices could be identified as dependence on powerful customers. On the other, not paying interest to the sustainable operations of suppliers also could be attributed to the dependence of the manufacturers on large suppliers. In their interviews with the researcher they stated their inability to influence suppliers.

\section{Conclusion and Managerial Implications}

Organizations are part of the society. So they have responsibility towards the society in turn. The expectations of the society from an organization are different from one party to another. Though as a whole there are environmental, social and economic requirements that are expected from an organization by the society. The parties who are interested in the activities of an organization are called stakeholders. Organizations attempt to maintain legitimacy in the eyes of stakeholders. This leads to a social contract between the society and the organization. There were many instances highlighted in literature where legitimacy amounted only to legal compliance where the social contract was questionable. This study investigated the legitimacy of apparel 
manufacturing organizations of Sri Lanka in their international operations. The interviews with four of the senior managers of manufacturing organizations revealed that their sustainable operations are highly dependent on the requirements of the powerful customers. It raised a question as to whether the manufacturers in a developing country can fulfill the social contract with only confirming to the legal obligations of customers.

This study contributed to knowledge by investigating how an organization in a developing country could maintain a social contract in a framework of legitimacy.

\section{References}

Agrawal, N., \& Smith, S. A. (2015). Retail Supply Chain Management: Quantitative Models and Empirical Studies (Vol. 223): Springer.

Banerjee, S. B. (2008). Corporate social responsibility: The good, the bad and the ugly. Critical sociology, 34(1), 51-79. https://doi.org/10.1177/0896920507084623

Braun, V., \& Clarke, V. (2006). Using thematic analysis in psychology. Qualitative research in psychology, 3(2), 77-101. https://doi.org/10.1191/1478088706qp063oa

Carter, C. R., \& Rogers, D. S. (2008). A framework of sustainable supply chain management: moving toward new theory. International Journal of Physical Distribution \& Logistics Management, 38(5), 360-387. https://doi.org/10.1108/09600030810882816

Chelli, M., Durocher, S., \& Richard, J. (2014). France's new economic regulations: insights from institutional legitimacy theory. Accounting, Auditing \& Accountability Journal. https://doi.org/10.1108/AAAJ-07-2013-1415

Choi, T. M. (2013a). Local sourcing and fashion quick response system: The impacts of carbon footprint ax. Transportation Research Part E: Logistics and Transportation Review, 55, 43-54. https://doi.org/10.1016/j.tre.2013.03.006

Cox, A. (2004). The Art of the Possible: Relationship Management in Power Regimes and Supply Chains. Supply Chain Management: An International Journal, 9(5), 346-356. https://doi.org/10.1108/13598540410560739

Deegan, C. (2002). The legitimising effect of social and environmental disclosures-a theoretical foundation. Accounting, Auditing \& Accountability Journal, 15(3), 282-311. https://doi.org/10.1108/09513570210435852

Elkington, J. (1998). Accounting for the Triple Bottom Line. Measuring Business Excellence, 2(3), 18-22. https://doi.org/10.1108/eb025539

Foley, K. J. (1995). Meta Management A Stakeholder/Quality Management Approach to Whole -of- Enterprise Management. Australia: Standards Australia.

Freeman, R. E. (1994). The Politics of Stakeholder Theory: Some Future Directions. Business Ethics Quarterly, 4(4), 409-421. https://doi.org/10.2307/3857340

Granovetter, M. S. (1992). Economic Institutions as Social Constructions: A Framework for Analysis. Acta Sociologica, 35(1), 3-11. https://doi.org/10.1177/000169939203500101

Gray, R., Owen, D., \& Maunders, K. (1988). Corporate social reporting: emerging trends in accountability and the social contract. Accounting, Auditing \& Accountability Journal, 1(1), 6-20. https://doi.org/10.1108/EUM0000000004617

Hollos, D., Blome, C., \& Foerstl, K. (2012). Does Sustainable Supplier Co-operation Affect Performance? Examining Implications for the Triple Bottom Line. International Journal of Production Research, 50(11), 2968-2986. https://doi.org/10.1080/00207543.2011.582184

Huo, B., Tian, M., Tian, Y., \& Zhang, Q. (2019). The dilemma of inter-organizational relationships. International Journal of Operations \& Production Management. https://doi.org/10.1108/IJOPM-07-2017-0383

Hussain, M. F., Moina Hussain, R. A., \& Ijaz, R. (2012). Eastern perspective of corporate social responsibility: an exploratory study. African Journal of Business Management, 6(3), 1124-1129. https://doi.org/10.5897/AJBM11.2395

Islam, M. A., \& Deegan, C. (2008). Motivations for an organisation within a developing country to report social responsibility information. Accounting, Auditing \& Accountability Journal.

Krause, D. R., \& Ellram, L. M. (1997). Success Factors in Supplier Development. International Journal of 
Physical Distribution \& Logistics Management, 27(1), 39-52. https://doi.org/10.1108/09600039710162277

Laplume, A. O., Sonpar, K., \& Litz, R. A. (2008). Stakeholder theory: Reviewing a theory that moves us. Journal of management, 34(6), 1152-1189. https://doi.org/10.1177/0149206308324322

Liker, J. K., \& Choi, T. Y. (2004). Building Deep Supplier Relationships, Harvard Business Review, 1-11.

Luken, R. A. (2006). Where is developing country industry in sustainable development planning? Sustainable Development, 14(1), 46-61. https://doi.org/10.1002/sd.267

Moretto, A., Laura, M., Caniato, F., Danese, P., Caridi, M., Spina, G., ... ianesi, A. (2012). Sustainability in the Fashion Supply Industry: An Important Source of Supply Chain Innovation. In Annual Academic Sessions of Decision Sciences Institute, 75501-75512.

Perrot, B. (2014). The Sustainable Organization: Blueprint for an Integrated Model. Journal of Business Strategy, 35(3), 26-37. https://doi.org/10.1108/JBS-07-2013-0061

Pullman, M. E., \& Dillard, J. (2010). Values based supply chain management and emergent organizational structures. International Journal of Operations \& Production Management, 30(7), 744-771. https://doi.org/10.1108/01443571011057326

Regan, M. C. (1998). Corporate speech and civic virtue. Debating democracy's discontent: Essays on American politics, law and public philosophy, 289-306. https://doi.org/10.1093/0198294964.003.0023

Reuter, C., Foerstl, K., Hartmann, E., \& Blome, C. (2010). Sustainable global supplier management: the role of dynamic capabilities in achieving competitive advantage. Journal of Supply Chain Management, 46(2), 45-63. https://doi.org/10.1111/j.1745-493X.2010.03189.x

Sarkis, J., Helms, M. M., \& Hervani, A. A. (2010). Reverse logistics and social sustainability. Corporate SocialResponsibility and Environmental Management, 17(6), 337-354. https://doi.org/10.1002/csr.220

Schaltegger, S., \& Burritt, R. L. (2014). Measuring and Managing Sustainability Performance of Supply Chains: Review and Sustainability Supply Chain Management Framework. Supply Chain Management: An International Journal, 19(3), 232-241. https://doi.org/10.1108/SCM-02-2014-0061

Seuring, S., \& Mu"ller, M. (2008a). Core issues in sustainable supply chain management - a delphi study. Business Strategy and the Environment, 17(8), 455-466. https://doi.org/10.1002/bse.607

Wallenburg, C. M., \& Schäffler, T. (2014). The interplay of relational governance and formal control in horizontal alliances: a social contract perspective. Journal of Supply Chain Management, 50(2), 41-58. https://doi.org/10.1111/jscm.12041

Warren, R. (1999). Company legitimacy in the new millennium. Business Ethics: A European Review, 8(4), 214-224. https://doi.org/10.1111/1467-8608.00156

Wei, Z., Shen, H., Zhou, K. Z., \& Li, J. J. (2017). How does environmental corporate social responsibility matter in a dysfunctional institutional environment? Evidence from China. Journal of Business Ethics, 140(2), 209-223. https://doi.org/10.1007/s10551-015-2704-3

Wilding, R., Wagner, B., Ashby, A., Leat, M., \& Hudson-Smith, M. (2012). Making connections: a review of supply chain management and sustainability literature. Supply Chain Management: An International Journal.

Windsor, D. (2001). Corporate Social Responsibility: A Theory of the Firm Perspective: Some Comments.

Woodward, D. G., Edwards, P., \& Birkin, F. (1996). Organizational legitimacy and stakeholder information provision 1. British journal of management, 7(4), 329-347. https://doi.org/10.1111/j.1467-8551.1996.tb00123.x

Zhu, Q., \& Sarkis, J. (2004). Relationships between operational practices and performance among early adopters of green supply chain management practices in Chinese manufacturing enterprises. Journal of operations management, 22(3), 265-289. https://doi.org/10.1016/j.jom.2004.01.005

\section{Copyrights}

Copyright for this article is retained by the author(s), with first publication rights granted to the journal.

This is an open-access article distributed under the terms and conditions of the Creative Commons Attribution license (http://creativecommons.org/licenses/by/4.0/). 